\title{
Analysis of Technological Pedagogical Content Knowledge (TPACK) Capabilities of Prospective Chemistry Teachers on Chemical Bonding Materials
}

\author{
${ }^{\mathrm{t}}$ Kusumawati Dwiningsih \\ Department of Chemistry \\ Universitas Negeri Surabaya \\ Surabaya, Indonesia \\ kusumawatidwiningsih@unesa.ac.id
}

\author{
Sri Poedjiastoeti \\ Department of Chemistry \\ Universitas Negeri Surabaya \\ Surabaya, Indonesia \\ sripoedjiastoeti@yahoo.com
}

\author{
Muchlis \\ Department of Chemistry \\ Universitas Negeri Surabaya \\ Surabaya, Indonesia \\ muchlis_kimia@yahoo.co.id
}

\begin{abstract}
The education of prospective Chemistry teachers is faced with the issue of integration of content knowledge, pedagogy and technology (TPACK / technological pedagogical content knowledge). Prospective teachers are expected to become teachers who are skilled in teaching effectively, mastering material (Chemistry content) and able to utilize technology for learning. The purpose of this study is to analyze the ability of TPACK prospective Chemistry teachers in Basic Inorganic Chemistry courses. This research is a descriptive study to describe the ability of TPACK prospective chemistry teachers. The subjects of this study are students of Chemistry Education Study Program who took the Basic Inorganic Chemistry Course in the odd semester 2018/2019. The ability of TPACK teacher candidates is obtained by analyzing the CoR instrument and PaPeR.TPACK in this study includes three main components of teacher knowledge, namely content, pedagogy, and technology. Based on the analysis of CoRe and PaPeR, prospective teachers can arrange big ideas to develop teaching materials 3 to 5 big ideas; Chemistry teacher candidates are good at managing teaching time and have good abilities in choosing learning strategies $(85 \%)$. There are still $77 \%$ of prospective teachers showing difficulties in managing class effectively. In the aspect of mastery of content shows that $62 \%$ of prospective teachers have mastery of concepts correctly, while $38 \%$ have mastery of concepts that are not exhaustive, and there are those that lead to misconceptions. The use of learning resources based on information technology and computers still need to be maximized because it is still limited in type (power point, video, internet), still few use it (32\%), as well as the selection of learning resources and media that are less relevant for the achievement of basic competencies. The conclusion is that the ability of TPACK prospective teachers still needs to be improved in several aspects of mastery of content, pedagogics and technology.
\end{abstract}

Keywords-technological pedagogical and content knowledge, prospective teachers of chemistry, chemical bonds

\section{INTRODUCTION}

Chemistry studies include the structure of matter, composition, properties, changes and energy involved in these changes. Some concepts in the study of chemistry pose difficulties and errors for learners because most are related to abstract concepts. Learners who experience learning difficulties and misconceptions start from high school to tertiary level as reported (K.-CD Tan and Treagust, 1999). Taber also found learners having difficulty understanding central concepts in chemistry (DKC Tan and Treagust, 1999). Chemical concepts that become difficulties and errors in the concept of this learner are the core concepts and foundation of further chemistry learning or supporting branches of Natural Sciences (IPA) and other sciences.

Prospective chemistry teachers as learners at the tertiary level have experienced chemistry learning since middle school and have not escaped the difficulties and errors of this concept. One concept that is difficult to understand and becomes a problem for prospective teachers is chemical bonding. This problem arises due to prior knowledge of prospective teachers (Ozgur, Temel and Yilmaz, 2012). Sirhan (2007) suggests several factors that cause problems in learning chemical bonds, namely the composition of the chemistry curriculum that is passed by the learner, problems in working memory of learners, language and communication as well as student motivation (Sirhan, 2007) .

Chemical bonding is one of the most important topics in undergraduate learning, and the difficulties students face in understanding this concept have been the subject of much research (Tarhan, L., HA Kayali., RO Urek., 2008). Chemical bonding is an abstract chemical concept which is very difficult and complicated by teachers, students, and chemistry educators (K.-CD Tan and Treagust, 1999). More specifically, atomic structure, particle properties of matter, molecules, and chemical bonds are also considered abstract concepts. This is a topic that students find difficult (Abraham, Varghese and Tang, 2010) .

Teachers' knowledge in teaching has been studied by researchers for decades, resulting in many different ways to understand, develop, and enforce what teachers know and do. Research on knowledge for effective teaching in the 
1980s and 1990s illustrates it from different epistemological points of view, reflecting important shifts in our understanding of the special nature of teacher knowledge and knowledge. Research results from this period can find perspectives from the perspective of philosophy based on a review of professional knowledge [1], analysis of the concept of skills-based education, and the relationship between teacher's personal and professional knowledge [2], [3].

In the process of learning and teaching activities, the teacher must also be able to convey the material well because learning is a process of developing knowledge, skills, and new behavior in a person as a result of his interaction with a variety of information and the environment. Therefore, the teacher must be able to convey the information he knows correctly and right on target, namely the content of the correct material through good pedagogical activities [4].

Shulman (1987) defines the subject matter of teaching content material as content and pedagogical knowledge (PCK). Knowledge content and pedagogic identify specific sections of knowledge for teaching [2], [5][8]. PCK is a combination of content and pedagogy in the understanding of how certain topics and problems or issues are organized, represented and adjusted to the interests and abilities of diverse students, and explained in the form of instructions [2], [9]-[11]. Content and pedagogical knowledge is the easiest category to distinguish content specialist understanding from educators [12].

As time goes by and students' needs increase, teachers not only have to have PCK skills. However, teachers must be able to teach subject matter with technology more than just PCK. This is because the current teaching and learning process reflects the growing integration between computers and technology applications in the curriculum. The idea of integrating knowledge of subject matter, teaching or learning, and technology has existed since the increasing needs of students in the use and learning needs of technology. Accordingly, knowledge of technology, pedagogy, and content has become an integral part of teacher education programs to prepare prospective teachers where they teach using technology in teaching.

Based on Shulman's idea of PCK, Mishra and Koehler (2006) have added technology to PCK, and described TPCK as a relationship between technology, pedagogy, and content. TPCK is the foundation of good teaching with technology and requires an understanding of sustainability. Analysis of Technological Pedagogical Content Knowledge Ability concept representation using technology; pedagogical techniques that use technology in a constructive way to teach content; knowledge of what makes concepts difficult or easy to learn and how technology can help some of the problems students face; student's initial knowledge and epistemological theory, and knowledge of how technology can be used to build on existing knowledge and to develop new epistemology or strengthen old ones [12].

Therefore, teachers must be able to integrate technology into their teaching. An approach is needed that treats teaching as the interaction between what teachers know and how they apply what they know in interesting situations or contexts in their classrooms. There is no "one best way" to integrate technology into the curriculum. Instead, integration efforts must be designed creatively or structured for certain subjects and important ideas in a particular class context [2]

In order to carry out his new mission, the teacher must really understand cognition and a variety of different ways of learning. Teachers must also understand student development and various pedagogical concepts as well as they master the learning material and alternative assessments that are used to measure student learning outcomes. Thus, the teacher must be able to place the various substances of language and cultural differences, learning styles, talents, and intelligence as the basis for implementing the various teaching strategies he chooses [13][14].

Based on the above conditions, learning must be carried out on the basis of what students know and can do as well as how students think and learn to align the learning process with the performance needed in accordance with the individual needs of students. Seeing this reality, it is clear the teacher must really have superior characteristics so that he will be able to carry out his new mission in the education process. The creation of this superior teacher must be done both when the teacher goes through the teacher education process and when the teacher has carried out his position as an educator [15], [16].

Therefore, the author raises the theme of the problem regarding pedagogical technology and content knowledge, the author conducted an analysis of the prospective chemistry teacher majoring in Chemistry at Surabaya State University.

\section{METHODS}

The study was a descriptive study, in which the researcher did not give treatment to the research object. Researchers only take data without any changes. The subjects of this study were students who took Chemistry Teaching Management (PP Kimia) courses in the odd semester of 2017/2018, in one study group.

The instrument of data collection of TPACK ability of prospective teachers using CoRe (Content Representation) and PaP-eR (Pedagogical and Professional-experience Repertoire )[17], [18].

Descriptive analysis is performed on the data obtained. The results of CoRe (Content Representation) and PaP-eR (Pedagogical and Professional-experience Repertoire ) were analyzed in several aspects to obtain a profile of the ability of TPACK prospective Chemistry teachers. TPACK in this study includes three main 
components of teacher knowledge, namely content, pedagogy, and technology. Aspects used to analyze TPACK prospective teachers include: the selection of basic competencies and the number of ideas for teaching materials, time management, classroom management, mastery of materials, selection of teaching strategies, and selection of information technology/computer-based media in learning. Prospective teacher PCK data were analyzed descriptively as percentages.

\section{RESULTS AND DISCUSSION}

\section{a. Results}

Research has been conducted to obtain information about the ability of TPACK prospective Chemistry teachers. The results of the study are presented in Tables 1 and 2 below.

TABLE 1. RESULTS OF THE CONTENT REPRESENTATION (CORE) ANALYSIS OF PCK CHEMISTRY TEACHER CANDIDATES

\begin{tabular}{|c|c|c|}
\hline Code & Theory & $\begin{array}{c}\text { Large amount } \\
\text { of material ideas }\end{array}$ \\
\hline M-01 & Ion Bonding & 5 \\
\hline M-02 & Kovalen ties & 5 \\
\hline M-03 & Molecular Shape & 5 \\
\hline M-04 & $\begin{array}{c}\text { Inter Molecular } \\
\text { Force } \\
\end{array}$ & 4 \\
\hline
\end{tabular}

Table 1 shows that in the preparation of learning implementation plans, prospective teachers are able to determine the topic / material based on Basic Competence (KD) to be achieved. The material developed for each student is also different, consisting of topics for achieving Basic Competence (KD) in the Chemistry Department of UNESA. The number of big ideas to develop teaching materials there are 4 big ideas. To analyze TPACK the Content Representation (CoRe) Instrument is used. The CoRe instrument was developed by Loughran and his team [19], which is a representation of how the teacher thinks about the material to be taught at a certain level. Apart from CoRe, teacher PCK was also analyzed using PaPeR.

TABLE II. RESULTS OF THE PEDAGOGICAL AND PROFESSIONAL EXPERIENCE REPERTOIRE (PAPER) ANALYSIS OF PROSPECTIVE CHEMISTRY TEACHERS

\begin{tabular}{|c|c|c|c|c|c|c|}
\hline \multirow{2}{*}{ Code } & \multicolumn{6}{|c|}{ Problems that arise in PaPeR } \\
& \multicolumn{1}{|c|}{$\begin{array}{c}\text { Time } \\
\text { arange } \\
\text { ment }\end{array}$} & $\begin{array}{c}\text { Class } \\
\text { manag } \\
\text { ement }\end{array}$ & $\begin{array}{c}\text { Mastery } \\
\text { of } \\
\text { concepts }\end{array}$ & $\begin{array}{c}\text { Strategy } \\
\text { selection }\end{array}$ & $\begin{array}{c}\text { Media } \\
\text { use }\end{array}$ & $\begin{array}{c}\text { Asse } \\
\text { ssme } \\
n t\end{array}$ \\
\hline M-01 & $\sqrt{ }$ & & & & $\sqrt{ }$ & $\sqrt{ }$ \\
\hline M-02 & & & & $\sqrt{ }$ & \\
\hline
\end{tabular}

\begin{tabular}{|c|c|c|c|c|c|c|}
\hline \multirow{2}{*}{ Code } & \multicolumn{6}{|c|}{ Problems that arise in PaPeR } \\
\cline { 2 - 7 } & $\begin{array}{c}\text { Time } \\
\text { arange } \\
\text { ment }\end{array}$ & $\begin{array}{c}\text { Class } \\
\text { manag } \\
\text { ement }\end{array}$ & $\begin{array}{c}\text { Mastery } \\
\text { of } \\
\text { concepts }\end{array}$ & $\begin{array}{c}\text { Strategy } \\
\text { selection }\end{array}$ & $\begin{array}{c}\text { Media } \\
\text { use }\end{array}$ & $\begin{array}{c}\text { Asse } \\
\text { ssme } \\
n t\end{array}$ \\
\hline M-03 & $\sqrt{ }$ & $\sqrt{ }$ & & $\sqrt{ }$ & $\sqrt{ }$ \\
\hline M-04 & $\mathbf{4 6}$ & $\mathbf{7 7}$ & $\mathbf{3 8}$ & $\mathbf{1 5}$ & $\mathbf{6 2}$ & $\mathbf{1 2}$ \\
\hline $\begin{array}{c}\text { Percentage } \\
(\%)\end{array}$ & & & & & & \\
\hline
\end{tabular}

Table 2 shows that the Chemistry teacher candidates still experiencing problems in managing time teach that effective.

There are $46 \%$ of students identified as having difficulty managing time, and $54 \%$ of people are already good at managing time. This happens because prospective teacher students do not have enough teaching experience, so it is still constrained in managing time.

The results of this study also come from the reflection of prospective teachers. The following is a summary of the reflections of prospective teachers showing the obstacles in teaching presented in Table 3.

\section{TABLE III. SUMMARY OF REFLECTIONS ON PROSPECTIVE} TEACHERS IN LEARNING

\begin{tabular}{|c|c|}
\hline $\begin{array}{l}\text { Teacher's } \\
\text { personal } \\
\text { readiness }\end{array}$ & $\begin{array}{l}\text { Feeling nervous, lacking confidence, and afraid } \\
\text { of being wrong and forgetting the lesson } \\
\text { plan; teacher motion is still limited in front of } \\
\text { the class, formulating too many indicators } \\
\text { for short time allocation, trying to instill } \\
\text { moral / character values to students even } \\
\text { though it is still small. }\end{array}$ \\
\hline $\begin{array}{l}\text { Teacher } \\
\text { readiness when } \\
\text { implementing } \\
\text { learning }\end{array}$ & $\begin{array}{l}\text { Still weak in managing the class, learning is } \\
\text { still monotonous / ordinary, lacking in variety, } \\
\text { still hesitant in explaining the material, } \\
\text { giving assignments that } \\
\text { are still not relevant, not giving } \\
\text { questions that encourage interaction between } \\
\text { students in learning, not utilizing / writing on } \\
\text { the board, still confused when responding to } \\
\text { student questions, the structure of presentation } \\
\text { of the material is less coherent, difficulty } \\
\text { conditioning students when discussion } \\
\text { activities. }\end{array}$ \\
\hline $\begin{array}{l}\text { Time } \\
\text { management }\end{array}$ & $\begin{array}{l}\text { Time management is less attention, the use } \\
\text { of time that is not balanced for several } \\
\text { stages of learning activities. }\end{array}$ \\
\hline Media use & $\begin{array}{l}\text { Using media in the form of videos and power } \\
\text { points, too many images in each PPt slide, } \\
\text { visual aids are not representative, do not } \\
\text { prepare / use media, are lacking in the use of } \\
\text { contextual / real learning resources. }\end{array}$ \\
\hline
\end{tabular}




\begin{tabular}{|l|l|}
\hline $\begin{array}{l}\text { Learning } \\
\text { strategies }\end{array}$ & $\begin{array}{l}\text { Not sure about the chosen learning model, the } \\
\text { delivery of material is less effective because } \\
\text { more lectures, learning with quizzes, guessing } \\
\text { games with prizes, questions and answers, } \\
\text { group discussions and presentations are often } \\
\text { used in learning. }\end{array}$ \\
\hline
\end{tabular}

\section{b. Discussion}

The process of making CoRe starts from formulating big ideas related to specific topics that will be conveyed to students to facilitate understanding. The results showed that prospective teachers can formulate big ideas related to topics 3 to 5 big ideas. This important concept will later determine the breadth and depth of the material and the strategies applied by the teacher when learning. The selection of important concepts that will be conveyed to students should be based on curriculum demands [20].

The big idea of material can be the basis in the preparation of material or teaching material. The breadth and depth of teaching material can be analyzed from the competencies, learning indicators, and teaching materials developed by the teacher. The ability of teachers to develop the indicators and teaching materials can be maximized through the activities of lectures. Lecturers can also facilitate students to continuously improve their professional and pedagogical competencies through the provision of relevant learning resources, through practice and hands-on practice. The research results of Sukaesih \& Kartijono (2014) state that the use of competency-based microteaching textbooks and conservation characters can develop the personal and professional competencies of the teacher candidates. Apart from just knowing the material / teaching material to be taught, a teacher must understand and be able to integrate content knowledge into knowledge about the curriculum, learning, teaching and students. Such knowledge can eventually lead the teacher to arrange learning situations according to individual and group needs of students. Such knowledge is expressed as a pedagogical content knowledge / PCK [21].

Based on the results of the PaPeR analysis, prospective teachers experience constraints in class management of $77 \%$. The problem that generally arises for prospective teachers who are just beginning to carry out learning in class is effective classroom management. This can occur because of the complexity of learning in the classroom that is not known before the teacher so that the teacher candidates do not yet have a way / technique to manage students. Teacher still focusing on self-control to successfully teach in the classroom, the condition of the surrounding environment has not been a particular concern. Class conditions that support the learning process, the condition of students who always focus on learning should be the attention of teachers in managing effective learning. Pedagogic knowledge and experience in implementing learning needs to be continually developed so that prospective teachers have sensitivity in managing effective learning.

In

mastering

concepts,

of prospective teachers have mastered concepts/teachi ng materials correctly, there are still 38\% who have low mastery of concepts, and some lead to misconceptions. This can occur because the ability of material analysis of each student is still poorly trained, because generally students learn textually. A teacher who has good content knowledge will be able to construct material elements simultaneously in working memory, pay attention to students' initial knowledge by giving direction, the material is not delivered at once or consider prerequisite knowledge [22]. The results showed that one of the factors that made it possible to improve the ability of teachers was to enrich PCK, which is a special combination of content knowledge and pedagogical knowledge that was built over time and experience, so as to produce professional teachers [17].

Generally students have good abilities in choosing teaching strategies $(85 \%)$, but there are still $15 \%$ having difficulty in choosing teaching strategies. Students have been able to choose and determine the right strategy for achieving basic competent, only the ability to implement learning strategies that are varied and "challenging" still need to be improved. Challenging learning strategies are learning strategies that are able to facilitate students' active learning, use a variety of learning resources and are able to optimize student learning experiences.

Regarding the use of teaching media, teachers have chosen instructional media in the form of Power point slide, pictures /charts/cards, videos, realia objects /objects, films. However, prospective teachers have not been able to optimally utilize the media in learning, that is still identified $62 \%$ of prospective teachers have not created active interaction between students and the media. Related to the knowledge and ability to apply technology, especially information technology in learning, it needs to be studied more deeply considering the PaPeR instrument used does not intend to identify the subject's ability to utilize information technology knowledge specifically. Chai, et.al. (2013), explains what is meant by technological knowledge is knowledge of how to use ICT hardware and software and related peripherals, for example knowledge of how to use the web (wiki, facebook, blogs, etc.) as a tool. In recent years technology has played an important role in turning education into more progressive and interactive activities. But the use of technology itself does not produce positive results in the quality of learning and student achievement. Teachers must be competent in subject knowledge, pedagogical skills and technological knowledge [23]. Furthermore Chai, et al. (2013) explains when 
technology knowledge is integrated with the TPACK element TPK, TCK, and TPACK will appear. TPK is knowledge about the existence and specifications of various technologies to enable teaching approaches without reference to subject matter, for example using ICT as a cognitive tool and computer-supported collaborative learning [24]. TCK is knowledge about how to use technology to research and create content in different ways without consideration about teaching, for example knowledge about online dictionaries and statistical programs in SPSS.

TPACK is knowledge using various technologies to be taught and represents knowledge of specific subject content. Thus $62 \%$ of the above mentioned subjects could not be identified what percentage had difficulties in mastering TPK and/ TCK and/TPACK. Furthermore Chai, et al. (2013) explain the integration of ICT into the curriculum inevitably involving the three basic dimensions of TPACK, namely $\mathrm{TK}, \mathrm{PK}$, and $\mathrm{CK}$. One thing that is relatively difficult to label learning as integrated ICT if there are basic elements missing. If the teacher is able to design TPACK integrated lessons, student learning can be improved. Thus it becomes very important to continuously improve the understanding of the T component of TPACK to prospective teacher students.

In the aspect of the assessment or the assessment plan, students generally already made an assessment instrument properly, even though the instruments are made incomplete to assess aspects o cognitive, active psychomotor. PCK development requires a long process to obtain new sources of skills and knowledge needed to become professional teachers who are experts in their fields. Chai, et al. (2013) stated that the effort to develop a rubric to assess the quality of learning according to various TPACK constructions is a meaningful/ important field of study. It offers a comprehensive way to evaluate the ICT integrated lessons that are designed, so that helps educators to identify weaknesses and strengthen the design of the eyes of college [24]. Chai, et al. (2013) suggests investigating how students' ideas about learning certain content (Learning Content Knowledge / LCK according to PCK), learning with technology (TLK according to TPK), and knowledge of technology content can help tell teachers what can or should be done in the classroom.

Based on the teacher's reflective journal, there are obstacles that are still being felt or experienced. This gives feedback and as an evaluation that prospective teachers still need to be guided, trained and given facilities through lectures to improve their teaching abilities.

$$
\text { Mastery of content and }
$$

pedagogical Chemistry teacher candidates still needs to be optimized or several aspects, through various methods /techniques. Alternatives that can be selected among others to provide books teaching that can be used as a guide to teachers in developing pedagogical abilities and mastery of Chemical content.

Research in the field of science shows that many teacher candidates are unaware of the importance of PCK as indicated by a lack of understanding of certain subject matter and knowledge that has not been integrated . PCK has a role in offering thinking strategies, about learning to teach science, can help teachers and students choose tips and tricks on how to teach, and encourage them to start exploring understanding of practices based on a better relationship between learning objectives and the learning process [17].

The involvement of direct discussions with experts is very helpful for teachers at the beginning of their careers to find great ideas to be taught. Prospective teachers can develop PCK which has through discussions, interviews and collaborations with experienced teachers, reflective journal writing after doing the learning, and make the core framework it self.

\section{CONCLUSIONS}

The conclusion from this study is that the ability of TPACK prospective Chemistry teachers still needs to be improved in several aspects of mastery of content, pedagogics and technology. TPACK capability development requires a long process to obtain new sources of skills and knowledge needed to form professional teachers.

\section{REFERENCES}

[1] S. Cox and C. R. Graham, "Diagramming TPACK in practice: Using an elaborated model of the tpack framework to analyze and depict teacher knowledge," TechTrends, 2009.

[2] Matthew J. Koehler, Punya Mishra, M. Akcaoglu, and Joshua M. Rosenberg, The Technological Pedagogical Content Knowledge Framework for Teachers and Teacher Educators. 2013.

[3] J. H. L. Koh, C. S. Chai, W. Benjamin, and H. Y. Hong, "Technological Pedagogical Content Knowledge (TPACK) and Design Thinking: A Framework to Support ICT Lesson Design for 21st Century Learning," Asia-Pacific Educ. Res., 2015.

[4] S. S. K. Alan and T. Seng Chee, "Integrating technology into lessons using a TPACK-based design guide," in ASCILITE 2010 - The Australasian Society for Computers in Learning in Tertiary Education, 2010.

[5] D. Baser, T. J. Kopcha, and M. Y. Ozden, "Developing a technological pedagogical content knowledge (TPACK) assessment for preservice teachers learning to teach English as a foreign language," Comput. Assist. Lang. Learn., 2016.

[6] S. J. Jang and K. C. Chen, "From PCK to TPACK: Developing a Transformative Model for Pre-Service Science Teachers," J. Sci. Educ. Technol., 2010.

[7] V. J. Pop, E. P. Brouwers, H. Wijnen, G. Oei, G. G. Essed, and H. L. Vader, "Low concentrations of maternal thyroxin during early gestation: A risk factor of breech presentation?," BJOG An Int. J. Obstet. Gynaecol., 2004.

[8] J. H. L. Koh, C. S. Chai, and C. C. Tsai, "Examining the technological 
pedagogical content knowledge of Singapore pre-service teachers with a large-scale survey,” J. Comput. Assist. Learn., 2010.

[9] M. L. Niess, "Investigating TPACK: Knowledge Growth in Teaching with Technology,” J. Educ. Comput. Res., 2011.

[10]J. M. Rosenberg and M. J. Koehler, "Context and technological pedagogical content knowledge (TPACK): A systematic review," $J$. Res. Technol. Educ., 2015.

[11]G. Chittleborough, "Learning How to Teach Chemistry with Technology: Pre-Service Teachers' Experiences with Integrating Technology into Their Learning and Teaching," J. Sci. Teacher Educ., 2014.

[12]G. Kurt, P. Mishra, and Z. Kocoglu, "Technological Pedagogical Content Knowledge Development of Turkish Pre-service Teachers of English," in Society for Information Technology \& Teacher Education International Conference, 2013.

[13]B. Bos, "Professional development for elementary teachers using TPACK," Contemp. Issues Technol. Teach. Educ., 2011.

[14]F. Boschman, S. McKenney, and J. Voogt, "Exploring teachers' use of TPACK in design talk: The collaborative design of technology-rich early literacy activities," Comput. Educ., 2015.

[15]Q. Zheng, L. Chen, and D. Burgos, "The international comparison and trend analysis of the development of MOOCs in higher education," in Lecture Notes in Educational Technology, 2018.

[16]J. H. L. Koh, C. S. Chai, and C. C. Tsai, "Demographic factors, TPACK Constructs, and teachers' perceptions of constructivistOriented TPACK," Educ. Technol. Soc., 2013.
[17]I. Kermen, "Studying the Activity of Two French Chemistry Teachers to Infer their Pedagogical Content Knowledge and their Pedagogical Knowledge," in Understanding Science Teachers' Professional Knowledge Growth, 2015.

[18] WHO, “Data quality review,” WHO Press, 2017.

[19]J. Wallace and J. Loughran, "Science teacher learning," in Second International Handbook of Science Education, 2012.

[20]J. Loughran, "Pedagogy: Making Sense of the Complex Relationship Between Teaching and Learning," Curric. Inq., 2013.

[21]S. Rahayu, "Mengoptimalkan Aspek Literasi dalam Pembelajaran Kimia Abad 21," Pros. Semin. Nas. Kim. UNY 2017 Sinergi Penelit. dan Pembelajaran untuk Mendukung Pengemb. Literasi Kim. pada Era Glob., 2017.

[22] T. C. Lin, C. C. Tsai, C. S. Chai, and M. H. Lee, "Identifying Science Teachers' Perceptions of Technological Pedagogical and Content Knowledge (TPACK)," J. Sci. Educ. Technol., 2013.

[23]E. Baram and E. Uygun, "Putting technological, pedagogical, and content knowledge (TPACK) in action: An integrated TPACK-design(DBL) approach based learning," Australas. J. Educ. Technol., 2016.

[24] J. H. L. Koh, C. S. Chai, and C. C. Tsai, "Examining practicing teachers' perceptions of technological pedagogical content knowledge (TPACK) pathways: A structural equation modeling approach," Instr. Sci., 2013 